\section{Ukrainian Journal \\ of Educational Studies and Information Technology}

ISSN: 2521-1234 online

Vol. 7, Issue 2, 2019

UDC $378.147=111$

\title{
Technology in the classroom: using graphics tablets for ESP lessons in agrarian and technical universities
}

\author{
Viktoriia Lemeshchenko-Lagoda, Oleksandr Kurashkin \\ Dmytro Motornyi Tavria State Agrotechnological University, \\ Melitopol, Ukraine
}

\begin{tabular}{|c|c|}
\hline ARTICLE INFO & ABSTRACT \\
\hline History: & The article is devoted to the aspects of using of graphics tablets on \\
\hline $\begin{array}{l}\text { Received: } 15.05 .2019 \\
\text { Accepted: } 20.06 .2019 \\
\text { Published online: } 27.06 .2019\end{array}$ & $\begin{array}{l}\text { ESP lessons (English for specific purpose) by students of agrarian } \\
\text { and technical specialties. The main prerequisites for the } \\
\text { implementation of interactive teaching methods are determined, as } \\
\text { well as the expediency of using information and communication }\end{array}$ \\
\hline $\begin{array}{l}\text { Keywords: } \\
\text { interactive methods } \\
\text { graphics tablets } \\
\text { project technology } \\
\text { interactive approach } \\
\text { English for specific purposes (ESP) } \\
\text { English as a foreign language (EFL) } \\
\text { language competence }\end{array}$ & $\begin{array}{l}\text { technology (ICT) in order to prepare a competitive specialist that is } \\
\text { able to use various language tools in a concrete communicative } \\
\text { situation for the interaction among cultures. The necessity of } \\
\text { developing new approaches to the organization of the educational } \\
\text { process of learning English as a language for specific purpose, as } \\
\text { well as its improvement and modernization, is considered. The } \\
\text { importance of ICT implementation into the educational process and } \\
\text { its significance for raising students' learning and cognitive activity } \\
\text { and motivation are highlighted and clarified. }\end{array}$ \\
\hline
\end{tabular}

interaction skills

foreign language proficiency

(C) V. Lemeshchenko-Lagoda

(C) O. Kurashkin

This work is licensed under a "CC BY

4.0" license.

\section{Технології аудиторного навчання: використання графічних планшетів на заняттях з англійської мови фахового спрямування в аграрних та технічних 3BO}

Лемещенко-Лагода Вікторія Володимирівна, Курашкін Олександр Сергійович

Таврійський державний агротехнологічний університет імені Дмитра Моторного, Мелітополь, Україна 
Анотація. Стаття присвячена питанням використання графічних планшетів на заняттях з іноземної мови професійного спрямування студентами немовних спеціальностей аграрного та технічного профілю навчання. Визначено головні передумови застосування інтерактивних методів навчання, а також обгрунтовано доцільність використання інформаційно-комунікаційних технологій з метою підготовки конкурентоспроможного спеціаліста, здатного використовувати різноманітні мовні засоби, необхідні у конкретній комунікативній ситуації для спілкування в умовах сьогодення. Обумовлено потребу розробки нових підходів щодо організації навчального процесу під час вивчення іноземної мови за професійним спрямуванням, а також його удосконалення та модернізації.

Ключові слова: інтерактивні методи навчання; графічні планшети; проектні технології; інтерактивний підхід; Англійська мова за професійним спрямуванням; Англійська як іноземна мова; мовна компетенція; навички взаємодії; рівень володіння іноземною мовою.

\section{INTRODUCTION}

The modern stage in the development of Ukrainian society, renewal of all spheres of its social and spiritual life, development of foreign economic and political relations with other countries, introduces new requirements for training of future specialists from different fields. Along with professional competence that requires problem solving skills, graduates of higher education institutions should master critical and creative thinking skills, constructive dialogue and interaction skills, learn how to adapt quickly and make responsible decisions in a constantly changing world and the most important - to speak a foreign language fluently.

Expansion and intensification of interlingual and intercultural interaction requires a qualitatively new level of education that would meet international standards, contributed to the formation of a fully developed, competitive personality, able to use the various language tools which can be used in a concrete communicative situation for the interaction among cultures. Therefore, the methodology of foreign languages teaching needs to be diversified and updated.

All of these is possible only due to the use of information and communication technologies that has contributed to the corresponding changes in education. The multimedia development and use of multimedia products in the educational process have led to the need for the development of technologies that can serve for the quality improvement of specialists training that meet the modern requirements of labor market. Therefore, interactive technologies have long been one of the main components of educational process in general, and teaching at universities, in particular (Tomilin, Evdoshkina, \& Ol'hovskaja, 2014).

This issue was considered and deeply investigated by such researchers as M. Anisimova, E. Bogacheva, A. Carillo, J. Cejudo, F. Dominguez, T. Ozrokova, E. Polat, N. Talyzina and others.

In their works, they stress on the necessity of ICT implementation into the educational process and their importance in raising students learning and cognitive activity and motivation.

The objective of this article is to provide useful information on how graphics tablets can be used by EFL and ESP teachers during English language classes at the agrarian and technical universities.

\section{RESEARCH RESULTS}

Effective implementation of interactive technologies into the process of learning foreign languages is impossible without understanding and adapting its methods to educational goals and requirements.

N. Talyzina, a psychologist and a teacher, noted that the use of automated systems in studying is justified only when it leads to an increase in efficiency of learning, at least according to one of the following criteria (Talyzina, 1984):

1. increasing the motivational and emotional aspect of learning;

2. improving the quality of education;

3. reducing the time spent by the teacher and student on this problem (question);

4. decreasing of financial costs of training.

It is known that the purpose of the educational process organization is maximum intensity of 
each student's work during the entire lesson. The use of multimedia equipment contributes to given intensification of learning activities above. In this case, the language instructor is able to pay more attention (but, in no case, not to patronize) one or more students who show enough high language ability, and the rest of the students will not be overlooked - the reference information or the solution of a similar example (or plan of solution) will be displayed for them on the screen.

It suggests that in order to conduct the lesson (both lecture and practical), the teacher or English language instructor should have a clear understanding of the didactic possibilities of his or her multimedia equipment and be able to use these modern information technologies in a proper way. Therefore, the lesson should be carefully designed and prepared. It raises questions about selection and preparation of new training material, choice of forms and methods of its presentation, organization of feedback between students and English language instructor, which makes it possible to adjust the learning process in a timely manner, to manage it according to the goals and main tasks.

By the means of implementation of this approach, we mean different technical complexes which usually consist of computers, multimedia projectors, touch screens, web-cameras, graphics tablets and other means by which students learning and cognitive activity at the university is carried out (Gushchin, 2012).

Graphics tablet technology is invading the education field at an increasing pace. A great amount of lecturers all around the world widely use graphics tablets while teaching Engineering, Architecture, Arts and Design. Unfortunately, the EFL teachers are not among those ones who diversify their teaching by using these tools despite of all benefits they can provide, mostly because of the lack of correct understanding what the graphics tablet is and how it can be used during EFL or ESP lessons.

Speaking about graphics tablet, we mean a device with a surface (that is a sensitive area) where you can write and draw with a digital pen or stylus, and all the information is displayed on the computer monitor screen. It means that we can connect graphics tablet to the projector instead of the computer and use it as an alternative to the traditional blackboard.

The pen or stylus is a familiar tool for the human hand, so navigation and work on the PC with it, is convenient, accurate and ergonomic: the muscles of the hand are always relaxed, while the fingers and palm are in motion, which is useful for the development of hand motor skills and safe for users who spend a lot of time at the computer and use the tablet in their daily professional activities (Gerasimovich, \& Yakushenkova, 2013). All tablet pens and styluses are sensitive to pressure: the more pressure on them is, the thicker the line in the graphical editor is.

Taking into account the great and serious interest of students in information technologies, it is possible to use work with the tablet as a powerful tool not only for the creation of different tables and graphs but also for the development of motivation on the lessons of subjects which are closely connected to their future career and especially foreign languages.

The main aim of a foreign language teaching in higher non-language educational institutions is to prepare specialists with practical knowledge of a foreign language accordingly to their future professional field. By this we mean acquiring skills of a foreign language proficiency in different spheres of speech activity on the subjects determined by all kinds of needs (personal, public, professional, educational) and improving the vocabulary and grammar skills, which are already acquired by completing various tasks and solving problems in order to build a high English-language professional communicative competence (National Strategy, 2013).

Thus, the use of interactive forms of studying during English classes at the agrarian and technical universities will be effective if the content of the educational process is overlapping with future professional activities of students. As O. Zubenko points out, it is also necessary to ensure that theoretical knowledge in the process of active learning becomes conscious, so that the student develops and improves not only knowledge of the language, but could also connect them with future professional activities (Zubenko, 2008). 
For example, second-year students of the specialty "Agroengineering" while studying English as a language for the specific (professional) purpose, at the stage of systematization of acquired knowledge, during the lesson on the topic: "Principles of engine operation", are proposed to explain each cycle of the internal combustion engine operation. For this task students are divided into four microgroups. Each micro-group has got a laptop and a graphics tablet with a pen or a stylus on the desk. All the laptops are connected via a local area network (LAN) to each other and to the main computer. The instructor of English provides students with the access to the educational materials for the consolidation of the topic and preparing their own projects using graphics tablet technologies.

After that, students are able to begin the completion of their assignments. In order to do their tasks students should connect the graphics tablets to their laptops and open the graphic image editor. When all the necessary preparation is completed, students, working in a micro-group, can start making sketches, tables, graphs etc. depending on the requirements and tasks set by the English language instructor. So, the task, according to the topic of the lesson, is not only to design and depict a certain cycle of the engine's operation in the form of a scheme or drawing, but also to name the main components that are directly involved in a certain cycle of work and describe the process in English, both in written form and orally. Using graphics tablets, students should create their own mini-projects and present them to the audience. Students' performances of the four projects makes it possible to fully reproduce the main four stages of the internal combustion engine, namely intake, compression, power and exhaust, which allows to repeat and revise all the material that was explained during the lesson.

So, immediately after listening and working on the new topic in class, students get the task of representing and presenting one of the engine cycle of work. Next, each group is given a sample drawing (Fig. 1), which will be the base for their projects.

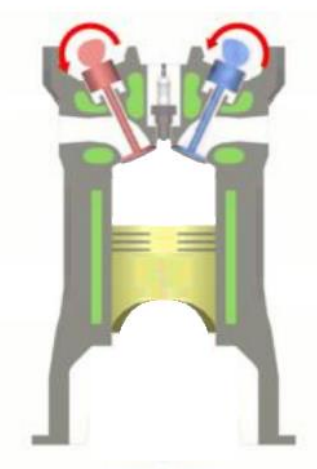

Fig. 1. Sample

After working out the given task in a group, the students should finish the drawing (depicting the movement and position of connecting rod and crankshaft, and movement of air-fuel mixture or burnt gases) and give a brief written description of the cycle. Thus, the possible projects and answers to this task may be as follows:

1. Intake stroke (Fig. 2). During the intake stroke the piston moves to BDC (Bottom Dead Center) and the intake valve opens. This movement of the piston draws a mixture of air and fuel into the cylinder (in a diesel this movement of the piston draws in air only) (Titova, 2014).

2. Compression stroke (Fig. 3). When the piston reaches BDC (Bottom Dead Center) it moves toward the cylinder head (inward motion). The valves do not open and the piston compresses the fuel mixture between the piston and the cylinder head (in a diesel the piston compresses air only) (Titova, 2014).

3. Power stroke (Fig. 4). When the piston reaches TDC (Top Dead Center), an electric spark ignites the fuel mixture in the combustion chamber of the gasoline engine (in a diesel engine the heat of the highly compressed air ignites the fuel). When the air-fuel mixture burns it moves the piston with great force (Titova, 2014).

4. Exhaust stroke (ig. 5). The exhaust stroke takes place when the piston moves up. The exhaust valve opens and the piston forces out the gases. The new cycle will begin in the cylinder (Titova, 2014). 


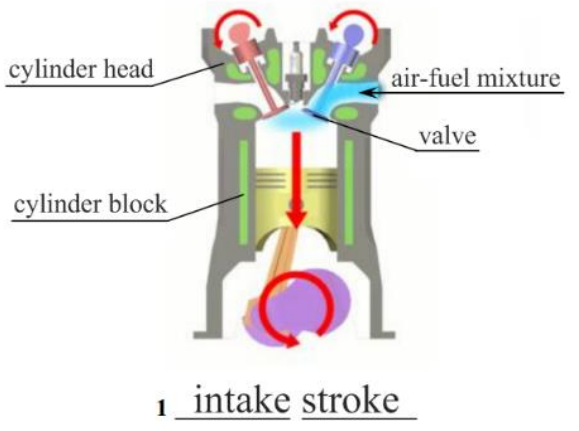

Fig. 2. Intake stroke

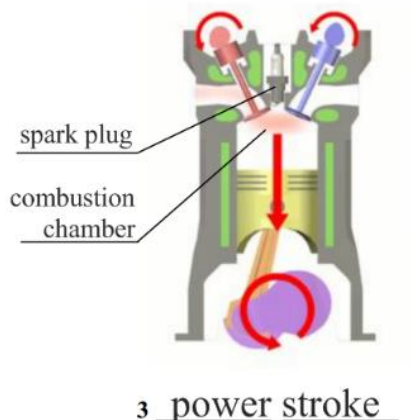

Fig. 4. Power stroke

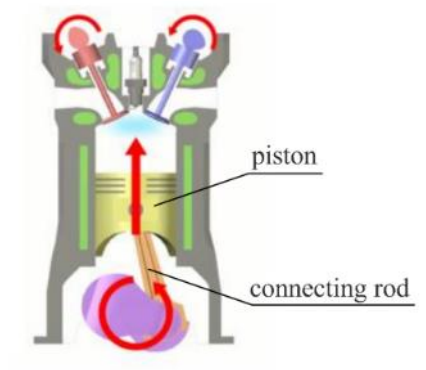

2 compression stroke

Fig. 3. Compression stroke

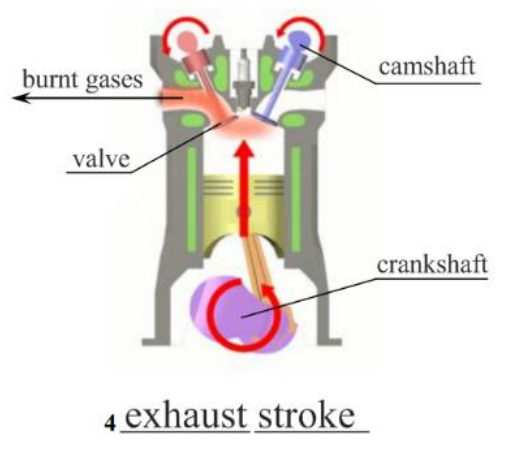

Fig. 5. Exhaust stroke
After the completion of given tasks the results should be stored so that the instructor could look them through, check and display them with help of the projector, giving the students the opportunity to present their projects to others and in such a way to revise what they have learnt.

Using this interactive method, EFL or ESP teachers can check the level of students communication skills, as well as vocabulary on a specific topic. Moreover, it should be noted that it gives the opportunity to students to improve the skills of rapid reaction and activates the search for synonyms and professional terms in English.

The main benefits of using graphics tablets for making such kinds of projects for students are:

- The graphics tablet is easy to use because of its lightweight and size especially in comparison with the laptop.

- You can easily draw or edit your project on the tablet by using the digital pen or stylus.

- With a stylus, you can move your hand and wrist into a natural drawing position (Revoy, 2010).
- A USB Graphics Tablet can be used in any application of your choice.

Speaking about advantages of graphics tablets, we cannot avoid mentioning some disadvantages, the main of which is required hand-eye coordination. Both students and teachers need previous training of working on graphics tablets because it is rather hard to draw on the tablet almost blindly and look straight at the monitor.

At the same time, it is worth pointing out that English language instructors also have some opportunities of using graphics tablet technology in the class. Among them:

- This technology allows to prepare the material for lesson in advance, to save it and to add quickly new information and ideas.

- Graphics tablet allows to "mark up" the documents, annotate on images and highlight the most important parts and passages attracting students' attention to the highly complicated concepts and cases (Carrillo, Cejudo, Domínguez, \& Rodríguez, 2013).

- Static lessons become more dynamic. 
- It encourages greater students participation allowing them to add new data, images etc., giving instructors the opportunity to work side by side with their students.

\section{CONCLUSIONS AND PERSPECTIVES FOR FURTHER STUDIES}

The conducted research makes it possible to point out that creating such an interactive learning atmosphere, we provide students with information-rich content such as presentations, diagrams, schemes while teaching grammar and vocabulary. At the same time, students become more engaged in educational process, proposing their own examples, making suggestions and remarks, improving not only their written but also oral skills.

Also this interactive method develops the ability of students to cooperate, whose performance is characterized by changing the strategy of interaction, provides an opportunity to involve students in educational interaction. The use of such technologies helps to form foreign language competence, which is determined by changing the style of communication, awareness of barriers to communication, the nature of the solution of communication problems, at a high level.

Besides, the convenient graphics tablet format encourages creativity - to draw and to make own posters, presentations with no extra tools required. It allows students to include text, pictures, diagrams etc. With help of various filters and brushes, the desirable effects can be achieved by a few strokes of digital pen or stylus. In such a manner, students become creative force rather than passive knowledge recipients.

Moreover, such kind of training imitates future professional activity in a certain way and promotes the development of students' professional skills and the forming of foreign language competence. Creation of mini-projects using graphics tablets allows those who learn not only to reveal their intellectual abilities, creative imagination and creativity, but also feel themselves in a certain communicative role.

To draw the conclusion, we should point out that the introduction of interactive learning technologies into the practice of teaching foreign languages is an important component of improving the communicative skills of students of non-language specialties of the agrarian and technical universities, and contributes to improving the efficiency of students' speech competence forming. Moreover, we should stress that new interactive approaches to the modern educational process allow us to move from the simple accumulation of knowledge to the direct formation of specialists capable to make productive solutions. It can be achieved by involving students in creative graphic activities that favorably influences the intellectual growth of personality, their creative development, creates conditions for the growth of initiative and activity of student youth, encouraging them to become more independent in mastering new knowledge and integrating acquired knowledge.

\section{REFERENCES}

Carrillo, A., Cejudo, J. M., Domínguez, F., \& Rodríguez, E. (2013). Graphics tablet technology in second year thermal engineering teaching. Journal of Technology and Science Education (JOTSE), 3 (3), 102-112. DOI: http://dx.doi.org/10.3926/jotse.85. (in English).

Gerasimovich, N. V., \& Jakushenkova, I. Ju. (2013). Abilities of using of graphics tablet. Professional'noe obrazovanie, (2), 54-58. Retrieved from: http://ripo.unibel.by/assets/site/jpo/files/primer 2. pdf. (in Russian)

Gushchin, Ju. V. (2012). Interactive teaching methods in higher education. Dubna Psychological Journal, (2), 1-18. Retrieved from: http://hist.isu.ru/ru/staff/teacher/docs/programmi 2015/grushin_interact.pdf. (in Russian)

National Strategy for the Development of Education in Ukraine for the period up to 2021. (2013). Decree of the President of Ukraine No. 344/2013 dated June 25, 2013. Retrieved from: http://zakon4.rada.gov.ua/laws/show/344/2013. (in Ukrainian)

Revoy, D. (2010). Ergonomic of Graphics tablets. Retrieved from: https://www.davidrevoy.com/articl e30/ergonomic-of-graphics-tablets.html (in English)

Talyzina, N. F. (1984). Management of the process of knowledge assimilation. Moscow: MGU. (in Russian)

Titova, O. A. (2014). Professional English For Tractors and Farm Machines: educational and methodical manual. Melitopol: Tavria state agrotechnological university. (in English) 
Tomilin, S. A., Evdoshkina, Ju. A., \& Ol'hovskaja, R. A. (2014). Practical application of interactive teaching methods in computer graphics classes. Inzhenernyj vestnik Dona, (3). Retrieved from: http://ivdon.ru/ru/magazine/archive/n3y2014/2492. (in Russian)
Zubenko, O. V. (2008). Interactive technologies of teaching in the study of foreign languages at the technical university. Visnyk Vinnytskoho politekhnichnoho instytutu, 4, 119-122. (in Ukrainian)

\section{About the authors:}

Viktoriia Lemeshchenko-Lagoda, Teacher of the Department of Foreign languages, Dmytro Motornyi Tavria State Agrotechnological University (18 B. Khmelnytsky Ave, Melitopol, Ukraine, 72310), ORCID: https://orcid.org/0000-0002-1080-5510, viktoriia.lemeshchenko-lagoda@tsatu.edu.ua

Oleksandr Kurashkin, Student of the Mechanical and Technological Faculty, Dmytro Motornyi Tavria State Agrotechnological University (18 B. Khmelnytsky Ave, Melitopol, Ukraine, 72310), ORCID: https://orcid.org/00000002-8267-4695, o.kurashkin@gmail.com

Про авторів:

Лемещенко-Лагода Вікторія Володимирівна, викладач-стажист кафедри іноземних мов, Таврійський державний агротехнологічний університет імені Дмитра Моторного (пр. Б. Хмельницького, 18, м. Мелітополь, Україна, 72310), ORCID: https://orcid.org/0000-0002-1080-5510， viktoriia.lemeshchenkolagoda@tsatu.edu.ua

Курашкін Олександр Сергійович, студент механіко-технологічного факультету, Таврійський державний агротехнологічний університет імені Дмитра Моторного (пр. Б. Хмельницького, 18, м. Мелітополь, Україна, 72310), ORCID: https://orcid.org/0000-0002-8267-4695, o.kurashkin@gmail.com 